\title{
Immunoreactivity of CD10 and inhibin alpha in differentiating hemangioblastoma of central nervous system from metastatic clear cell renal cell carcinoma
}

\author{
Shih-Ming Jung ${ }^{1,2}$ and Tseng-tong Kuo ${ }^{1}$ \\ ${ }^{1}$ Department of Pathology, Chang Gung Memorial Hospital, Taoyuan, Taiwan and ${ }^{2}$ Department of Pathology, \\ Chang Gung Children's Hospital, Taoyuan, Taiwan
}

\begin{abstract}
The differential diagnosis between hemangioblastoma of the central nervous system and metastatic clear cell renal cell carcinoma can be problematic, because they may share striking morphologic similarities. Since CD10 is expressed in clear cell renal cell carcinoma, while inhibin alpha is expressed in hemangioblastoma, we used CD10 and inhibin alpha (inhibin A) to study their possible use in the distinction of these two entities. A total of 22 cases of cerebellar hemangioblastoma, five cases of metastatic clear cell renal cell carcinoma to the central nervous system, and 16 primary cases of clear cell renal cell carcinoma were studied with immunohistochemical staining of both CD10 and inhibin A. All 22 cases of hemangioblastoma were immunonegative for CD10 in the stromal cells. In contrast, all five cases of metastatic clear cell renal cell carcinoma and 16 cases of primary clear cell renal cell carcinoma showed positive CD10 membranous staining. In all, 20 cases of hemangioblastoma (20/22, 91\%) expressed inhibin $A$ in the stromal cells. Two cases of primary clear cell renal cell carcinoma $(2 / 16,13 \%)$ and three cases of metastatic clear cell renal cell carcinoma $(3 / 5,60 \%)$ showed immunopositivity for inhibin A. In conclusion, in addition to the immunostaining of inhibin A, CD10 is a superior marker for distinguishing between a hemangioblastoma and a metastatic clear cell renal cell carcinoma. Modern Pathology (2005) 18, 788-794, advance online publication, 3 December 2004; doi:10.1038/modpathol.3800351
\end{abstract}

Keywords: CD10; hemangioblastoma; inhibin alpha; clear cell renal cell carcinoma

Hemangioblastoma is a highly vascular neoplasm commonly involving the cerebellum and spinal cord. It can occur sporadically or in association with von Hippel-Lindau syndrome. ${ }^{1}$ The differential diagnosis between hemangioblastoma and metastatic clear cell renal cell carcinoma to the central nervous system can be difficult because striking morphologic similarities exist between them, in addition to the association between von HippelLindau disease and clear cell renal cell carcinoma. ${ }^{1-3}$ Studies have shown that loss of von Hippel-Lindau tumor suppressor gene on chromosome 3 is found in familial and sporadic cerebellar hemangioblastoma

Correspondence: Dr S-M Jung, MD, Department of Pathology, Chang Gung Memorial Hospital, No 5 Fu Hsin Road, Kwei San, Taoyuan 333, Taiwan.

E-mail: ming22@adm.cgmh.org.tw

Presented in part at the XV International Congress of Neuropathology, Turin, Italy, September 14-18, 2003 and the 93rd Annual Meeting of the United States and Canadian Academy of Pathology, Vancouver, March 6-12, 2004.

Received 26 August 2004; revised and accepted 25 October 2004; published online 3 December 2004 as well as clear cell renal cell carcinoma. ${ }^{4}$ However, since the clinical course and management of these two diseases are totally different, it is important to distinguish hemangioblastoma from metastatic clear cell renal cell carcinoma.

Immunohistochemical studies may be helpful in this setting. In most of the cases, the renal cell carcinomas showed immunopositive for epithelial membranous antigen (EMA) and immunonegative for neuron-specific enolase (NSE), while the hemangioblastoma showed immunopositive for NSE and immunonegative for EMA. ${ }^{2,5-7}$ The previous reports presented uniformly effectiveness of EMA in this distinction. ${ }^{2,5}$ However, equivocal results with neoplasms staining for both markers or failure to stain for either marker could happen. Therefore, further research for methods to differentiate these two entities is necessary.

CD10, the common acute lymphoblastic leukemia antigen, is a $94-\mathrm{kDa}$ cell surface neutral metalloendopeptidase that degrades bioactive peptides. It has been used as a diagnostic tool for acute leukemia and certain malignant lymphoma. ${ }^{8}$ Recent studies 
demonstrated that CD10 was expressed in a variety of nonhematopoietic tumors, including renal cell carcinoma, carcinoma of gastrointestinal and genitourinary tracts, endometrial stromal sarcoma, and malignant Mullerian mixed tumor. ${ }^{9}$ Previous studies suggested that the function of CD10 in the kidney may be to cleave peptides that function in renal autoregulation in the maintenance of water and sodium metabolism. ${ }^{10}$ It was taken as a specific marker for renal cell carcinoma. ${ }^{11}$

Inhibin, a dimeric $32-\mathrm{kDa}$ peptide hormone that belongs to the transforming growth factor beta family, is normally produced by ovarian granulosa cells and testicular Sertoli cells. ${ }^{12}$ Inhibin comprises an alpha $(\alpha)$ subunit (inhibin A) and a beta $(\beta)$ subunit. Inhibin A is expressed in the sex cord stromal tumor and adrenal cortical tumor. ${ }^{13,14}$ Expression of inhibin A has recently been described in hemangioblastoma. ${ }^{15}$

The aim of the present study was to explore the utility of antibodies of CD10 and inhibin A in the differential diagnosis of hemangioblastoma and clear cell renal cell carcinoma.

\section{Materials and methods}

Formalin-fixed, paraffin-embedded tissues of 22 hemangioblastomas, five metastatic clear cell renal cell carcinomas to the central nervous system, and 16 primary kidney clear cell renal cell carcinomas diagnosed from 1986 to 2003 were retrieved from the pathology files of a medical center in Taiwan. Clinical information was obtained from the patients' medical records. Only one case of hemangioblasto- ma showed signs associated with von HippelLindau disease.

Sections were immunostained using standard avidin-biotin peroxidase method augmented by heat-induced epitope retrieval buffer $(0.01 \mathrm{M}$ citrate, $\mathrm{pH}$ 6), biotin blocking system, and primary antibodies of CD10 (Monoclonal Mouse Antibody 56C6, dilution 1:10; Novocastra, Newcastle upon Tyne, UK), as well as inhibin A (Monoclonal Mouse AntiHuman Inhibin $\alpha$, clone R1, dilution 1:20; Dako, Carpinteria, CA, USA). In seven cases of hemangioblastoma, EMA (E29, 1:200, Dako) and NSE (BBS/ NC/VI-H14, 1:4000; Dako) were performed. The immunoreactivity was scored semiquantitative as follows: negative or $0(<10 \%)$, weak or $1+(10-$ $25 \%)$, moderate or $2+(26-50 \%)$, and strong or $3+(51-100 \%) .^{15}$

\section{Results}

\section{Clinical Findings}

A total of 22 patients with hemangioblastoma undergoing resection at this center were included in this study. All of the patients underwent curative surgery with a gross total resection. There were 10 females and 12 males ranging in age from 18 to 74 years (mean 42 years). In all, 19 tumors were located in the cerebellum, two in the cervical spinal cord, and one in the occipital lobe. A total of 21 cases had sporadic tumors. One case had von Hippel-Lindau disease and the tumor was multicentric. (Table 1 , case 22) None of these 22 patients had renal cell carcinoma.

Table 1 Results of immunohistochemical studies of 22 cases of hemangioblastoma

\begin{tabular}{|c|c|c|c|c|c|c|}
\hline Case & Age & Sex & Site & Follow-up & Inhibin $A^{\mathrm{a}}$ & $C D 10^{\mathrm{a}}$ \\
\hline 1 & 33 & $\mathrm{~F}$ & Cerebellum & $9 \mathrm{yr}$ & $1+$ & 0 \\
\hline 2 & 44 & $\mathrm{~F}$ & Spinal cord C2-3 & $4 \mathrm{mo}$ & $2+$ & 0 \\
\hline 3 & 19 & $\mathrm{~F}$ & Cerebellum & $1 \mathrm{mo}$ & 0 & 0 \\
\hline 4 & 28 & $\mathrm{~F}$ & Cerebellum & $3 \mathrm{mo}$ & $3+$ & 0 \\
\hline 5 & 45 & $\mathrm{M}$ & Cerebellum & $1 \mathrm{yr} 7 \mathrm{mo}$ & $1+$ & 0 \\
\hline 6 & 27 & $\mathrm{M}$ & Cerebellum & $6 \mathrm{mo}$ & $3+$ & 0 \\
\hline 7 & 74 & $\mathrm{~F}$ & Cerebellum & $1 \mathrm{yr} 8 \mathrm{mo}$ & $1+$ & 0 \\
\hline 8 & 47 & $\mathrm{M}$ & Cerebellum & 1 yr 6 mo & $3+$ & 0 \\
\hline 9 & 49 & $\mathrm{M}$ & Occipital lobe & $1 \mathrm{yr} 8 \mathrm{mo}$ & $2+$ & 0 \\
\hline 10 & 34 & $\mathrm{M}$ & Cerebellum & 1 yr $5 \mathrm{mo}$ & $2+$ & 0 \\
\hline 11 & 51 & $\mathrm{~F}$ & Cerebellum & $1 \mathrm{yr} 2 \mathrm{mo}$ & $3+$ & 0 \\
\hline 12 & 51 & $\mathrm{~F}$ & Cerebellum & $2 \mathrm{yr} 1 \mathrm{mo}$ & $3+$ & 0 \\
\hline 13 & 42 & $\mathrm{M}$ & Cerebellum & 2 yr $5 \mathrm{mo}$ & $3+$ & 0 \\
\hline 14 & 28 & $\mathrm{M}$ & Cerebellum & $2 \mathrm{yr}$ & $2+$ & 0 \\
\hline 15 & 46 & $\mathrm{M}$ & Cerebellum & $1 \mathrm{yr}$ & $3+$ & 0 \\
\hline 16 & 31 & $\mathrm{M}$ & Cerebellum & 2 yr $3 \mathrm{mo}$ & $2+$ & 0 \\
\hline 17 & 72 & $\mathrm{M}$ & Cerebellum & $2 \mathrm{yr} 10 \mathrm{mo}$ & $2+$ & 0 \\
\hline 18 & 58 & $\mathrm{~F}$ & Spinal cord C2 & $10 \mathrm{mo}$ & $1+$ & 0 \\
\hline 19 & 34 & $\mathrm{M}$ & Cerebellum & $1 \mathrm{mo}$ & $1+$ & 0 \\
\hline 20 & 18 & $\mathrm{M}$ & Cerebellum & $1 \mathrm{yr}$ & $2+$ & 0 \\
\hline 21 & 67 & $\mathrm{~F}$ & Cerebellum & $2 \mathrm{yr}$ & $2+$ & 0 \\
\hline 22 & 35 & $\mathrm{~F}$ & Cerebellum & 2 yr $6 \mathrm{mo}$ & 0 & 0 \\
\hline
\end{tabular}

${ }^{\mathrm{a}} 0:<10 \%, 1+: 10-25 \%, 2+: 26-50 \%, 3+: 51-100 \%$.

$\mathrm{yr}=$ years; $\mathrm{mo}=$ months. 
In all, 16 cases of clear cell renal cell carcinoma were included in this study. There were five females and 11 males ranging in age from 22 to 79 years (mean 63 years). Two of the patients had bilateral kidney tumors. One of the patients had metastatic renal cell carcinoma to the brain. Neither patients were associated with von Hippel-Lindau syndrome nor had both renal cell carcinoma and hemangioblastoma. In addition, five cases of metastatic clear cell renal cell carcinoma to the central nervous system were included. They were all males ranging in age from 52 to 68 years (mean 61 years).

\section{Histologic Findings}

All cases of hemangioblastoma demonstrated high vascular neoplasm with variable cellularity of stromal cells. Some were highly cellular, while others were composed of vascular networks and cystic spaces (Figure 1a). The stromal cells had
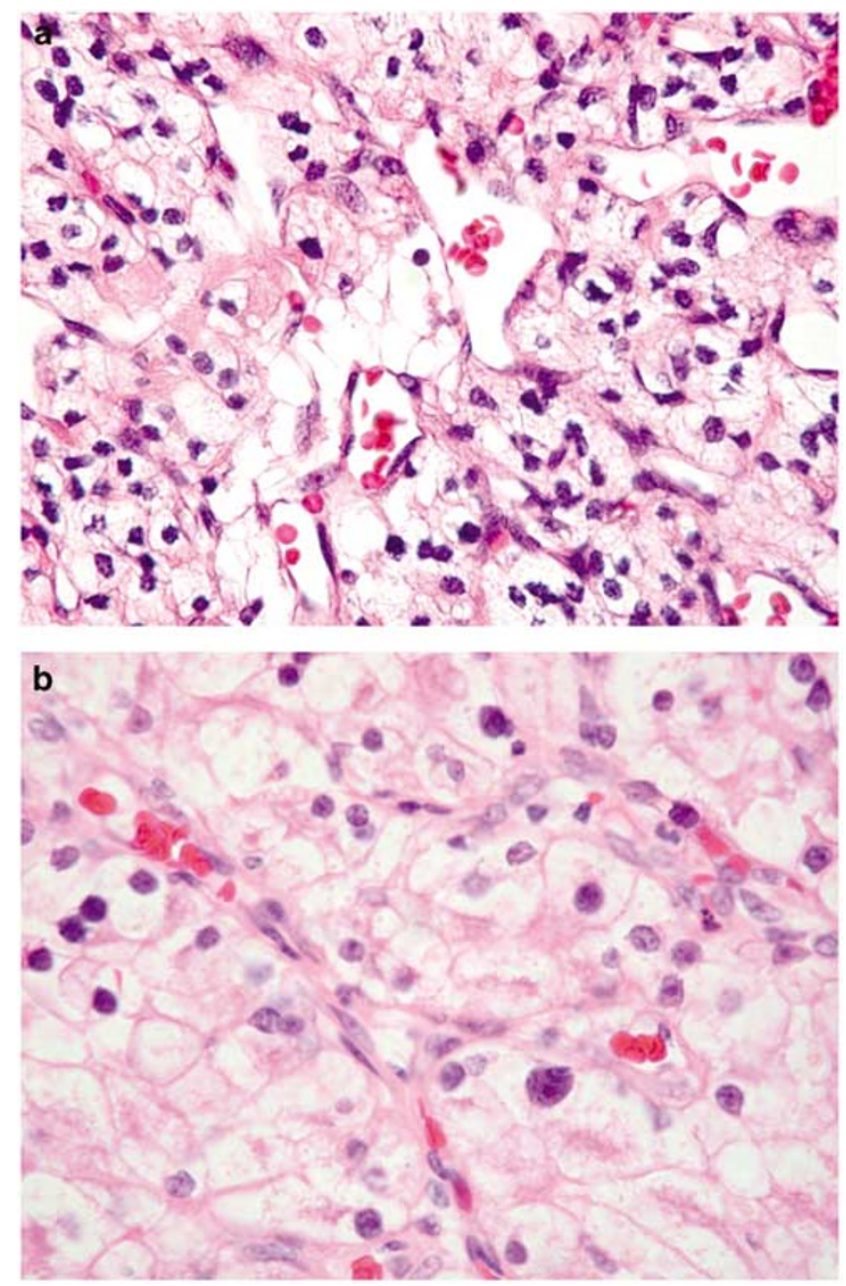

Figure 1 The stromal cells of hemangioblastoma had clear, foamy cytoplasm in vascular networks ( $\times 400$, H\&E stain) (a). Metastatic clear cell renal cell carcinoma showed abundant clear cytoplasm and nuclear pleomorphism nearly indistinguishable from hemangioblastoma ( $\times 400$, H\&E stain) (b). clear, foamy, lipid-laden cytoplasm or eosinophilic cytoplasm. Nuclear pleomorphism and atypia were predominant in three cases.

All of the 16 primary clear cell renal cell carcinoma cases and five metastatic clear cell renal cell carcinoma cases included in the study were of the clear cell type. There were 13 tumors with nuclear grade II, three nuclear grade III. Included in the primary clear cell renal cell carcinoma cases was one tumor that subsequently metastasized to the central nervous system.

The five cases of metastatic clear cell renal cell carcinoma to the central nervous system showed abundant clear cytoplasm and nuclear pleomorphism nearly indistinguishable from hemangioblastoma (Figure 1b).

\section{Immunohistochemical Findings}

Table 1 summarizes the results of immunohistochemical studies of 22 cases of hemangioblastoma.

All 22 hemangioblastoma cases were immunonegative for CD10 (Figure 2a). A total of 20 (91\%, 20/ 22) hemangioblastomas expressed inhibin $A$ in the stromal cells (Figure 2b). Strong and diffuse cytoplasmic staining of inhibin A was seen in seven cases, moderate staining was noted in eight cases, and weak immunoreactivity was seen in five cases. Two cases were immunonegative for inhibin A. In the seven cases of hemangioblastoma with immunostaining of EMA and NSE, all were positive for NSE and negative for EMA.

All 16 primary clear cell renal cell carcinomas showed positive CD10 membranous staining (Figure 3). Two cases expressed inhibin A in strong to moderate cytoplasmic staining, and the other 14 primary clear cell renal cell carcinoma cases were immunonegative for inhibin A. The one primary case with subsequent metastasis to the central nervous system had moderate staining of inhibin A.

All five metastatic clear cell renal cell carcinomas to central nervous system showed positive CD10 membranous staining. Two metastatic clear cell renal cell carcinomas showed immunonegativity for inhibin A, whereas three metastatic clear cell renal cell carcinomas expressed inhibin A with weak to moderate intensity of cytoplasmic staining (Figure 4).

Table 2 presents the positive rates of immunohistochemical studies of inhibin A and CD10 in hemangioblastomas and clear cell renal cell carcinomas in this series.

In this series, the sensitivity and specificity of using CD10 for discriminating clear cell renal cell carcinoma from hemangioblastoma is $100 \%(21 / 21)$ and $100 \%(22 / 22)$, respectively. The sensitivity and specificity of using inhibin A for distinguishing hemangioblastoma from clear cell renal cell carcinoma is $91 \%(20 / 22)$ and $76 \%(16 / 21)$, respectively. 

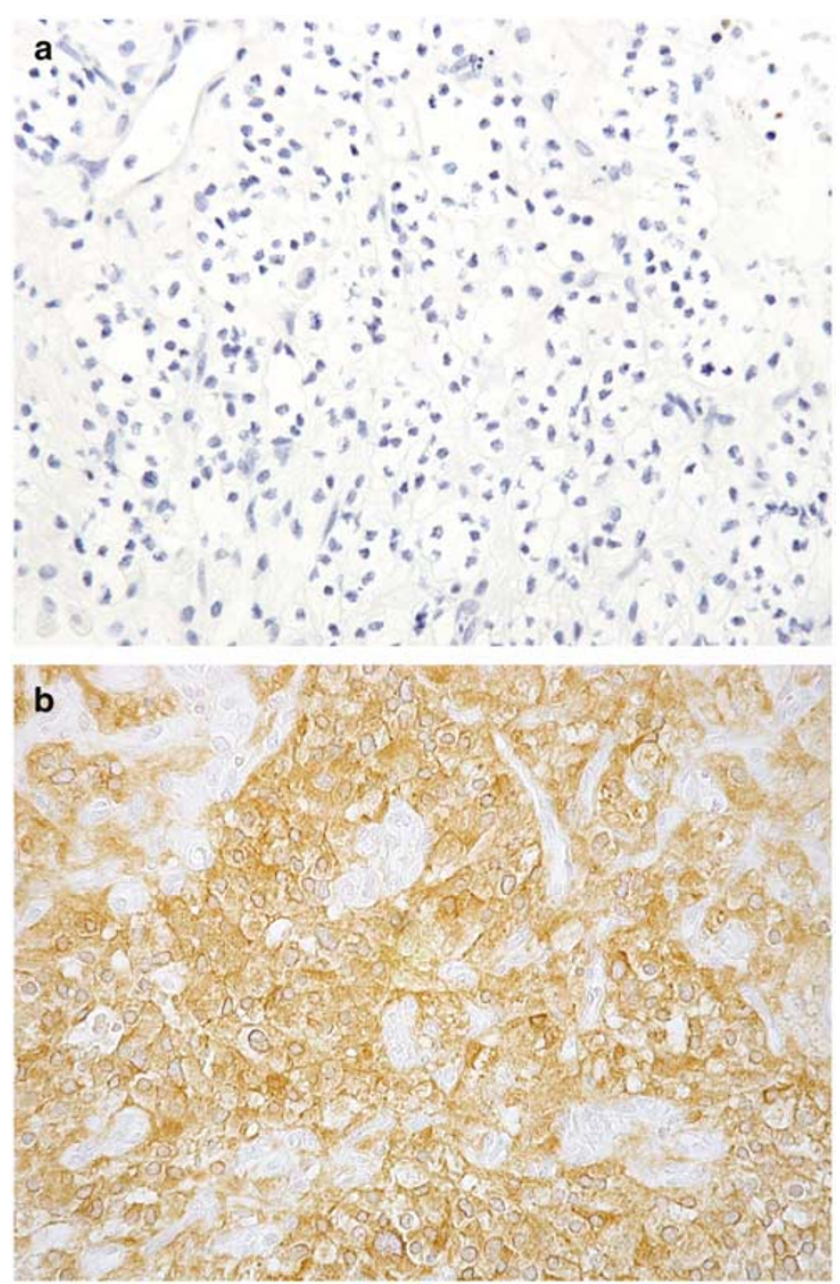

Figure 2 Hemangioblastoma was immunonegative for CD10 (a). Inhibin A was expressed in the stromal cells of most cases of hemangioblastoma (b).

\section{Discussion}

The differential diagnosis of a primary hemangioblastoma from a metastatic clear cell renal cell carcinoma to central nervous system has long been recognized as a particular difficulty. Since medical history and conventional histological techniques may not provide sufficient evidence to distinguish between them, variable immunohistochemical techniques have been investigated to characterize these two entities. Immunomarkers for clear cell renal cell carcinoma included pancytokeratin, EMA, and vimentin. However, none of these stainings is specific for clear cell renal cell carcinoma, and the characteristic immunoprofile for renal cell carcinoma displays overlap with other tumors that may be confused with renal cell carcinoma. ${ }^{16-21}$ The high percentage of CD10 staining of clear cell renal cell carcinoma has been described recently. ${ }^{11}$

The histogenesis of the stromal cells of hemangioblastoma remains unclarified. Immunoreactivity in the stromal cells includes: NSE, Leu M1, glial

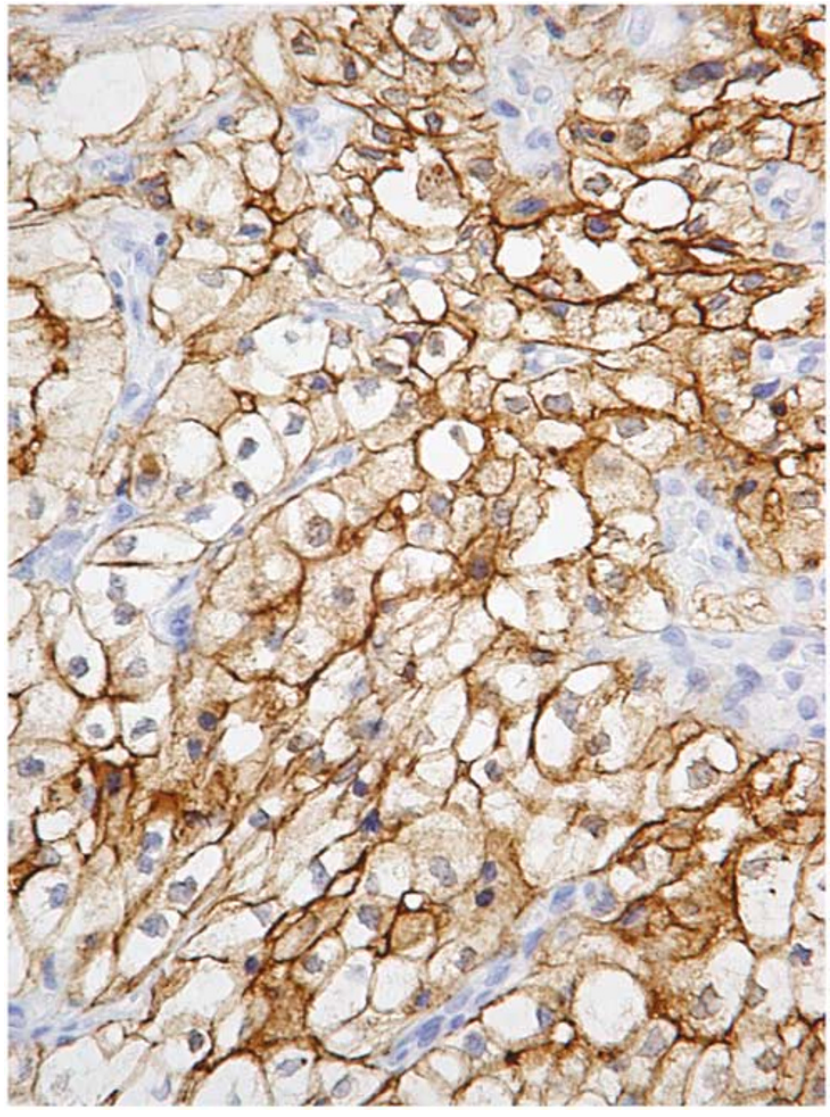

Figure 3 Clear cell renal cell carcinomas showed positive CD10 membranous staining.

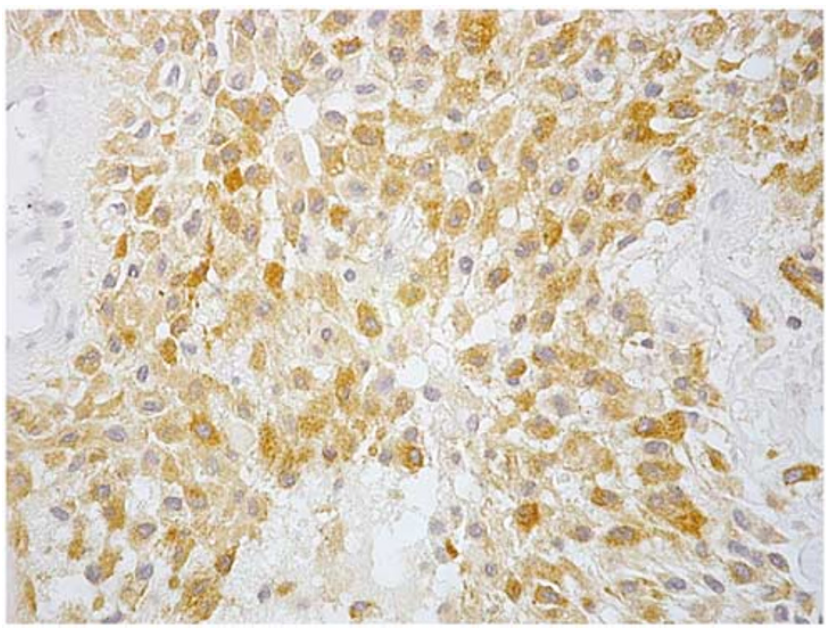

Figure 4 Some metastatic clear cell renal cell carcinomas expressed inhibin A.

fibrillary acidic protein, hormone receptor, vimentin, vascular endothelial growth factor, rennin, and erythropoietin. ${ }^{1,2,6,22-25}$ In early reports, stromal cells of hemangioblastoma are invariably negative for EMA and cytokeratin. Currently, an immunohistochemical panel of markers comprising of NSE and 
EMA provides the most valuable means of discriminating hemangioblastoma from clear cell renal cell carcinoma. In the majority of cases of hemangioblastoma, NSE is positive and EMA is negative, where the opposite is seen in cases of clear cell renal cell carcinoma. ${ }^{2,5}$ However, NSE is not a specific marker and the presence of weak cytoplasmic staining in some renal cell carcinomas weakened this distinction. ${ }^{5}$

Recently, inhibin A was demonstrated to be a useful marker in distinguishing hemangioblastoma from metastatic clear cell renal cell carcinoma. ${ }^{15}$ Inhibin A was consistently expressed in the stromal cells of hemangioblastoma, and was immunonegative in cases of clear cell renal cell carcinoma. ${ }^{13,15}$ However, the reliability of this immunochemical study is challenged by the fact that inhibin A has been reported to be immunopositive in case of renal cell carcinoma. ${ }^{26}$

In our study, the application of immunohistochemical panel with both inhibin A and CD10 solves the problem successfully. Table 3 summarizes the results of immunohistochemical studies of EMA, NSE, inhibin A, and CD10 for this distinction in previous reports as well as in this study. In this series, 20 of $22(91 \%)$ hemangioblastomas expressed inhibin A in the stromal cells, while none of the 22 hemangioblastomas showed immunopositive of CD10. In contrast, all 16 primary clear cell renal cell carcinomas and five metastatic clear cell

Table 2 Positive rates of immunohistochemical studies of inhibin A and CD10 of hemangioblastomas and clear cell renal cell carcinomas

\begin{tabular}{|c|c|c|c|}
\hline & $\begin{array}{c}\text { Total } \\
\text { number } \\
\text { of cases }\end{array}$ & $\begin{array}{c}\text { Number } \\
\text { of cases } \\
\text { with positive } \\
\text { CD10 (\%) }\end{array}$ & $\begin{array}{c}\text { Number } \\
\text { of cases } \\
\text { with positive } \\
\text { inhibin } A \\
(\%)\end{array}$ \\
\hline Hemangioblastomas & 22 & $0(0)$ & $20(91)$ \\
\hline $\begin{array}{l}\text { Primary clear cell renal } \\
\text { cell carcinomas }\end{array}$ & 16 & $16(100)$ & $2(13)$ \\
\hline $\begin{array}{l}\text { Metastatic clear cell renal } \\
\text { cell carcinomas }\end{array}$ & 5 & $5(100)$ & $3(60)$ \\
\hline
\end{tabular}

carcinomas to the central nervous system expressed CD10, and two of $16(13 \%)$ primary clear cell renal cell carcinomas and three of five $(60 \%)$ metastatic clear cell renal cell carcinomas also expressed inhibin A. This finding is compatible with the previous reports demonstrating that CD10 was immunopositive in 89 to $94 \%$ of cases of renal cell carcinoma. $^{9,11}$ However, the immunopositive rates of inhibin A in cases of primary clear cell renal cell carcinoma $(13 \%)$ and metastatic clear cell renal cell carcinoma to central nervous system $(60 \%)$ in this series were higher than those in previous reports. ${ }^{15,26}$

All the 16 primary clear cell renal cell carcinomas and metastatic clear cell renal cell carcinomas presented typical membranous staining of CD10 as described in the previous report. ${ }^{9}$ The immunoexpression of inhibin A in the stromal cells of 20 hemangioblastomas, and the cytoplasmic staining of inhibin A in the two primary clear cell renal cell carcinomas and three metastatic clear cell renal cell carcinomas were also typical. ${ }^{15,26}$ Our results suggest that CD10 can complement the use of inhibin A in the differential diagnosis of hemangioblastoma and metastatic clear cell renal cell carcinoma to central nervous system.

In our study, not only did CD10 detect all of the clear cell renal cell carcinomas but it also stained a large percent of tumor cells in each case. We found that $>10$ and $50 \%$ of tumor cells were stained in $100 \%(21 / 21)$ and $52 \%(11 / 21)$ of cases of clear cell renal cell carcinoma, respectively. However, inhibin $\mathrm{A}$ is expressed in the majority of hemangioblastomas with staining in a relatively lower percent of tumor cells in each case. The result showed that $>10$ and $50 \%$ of tumor cells were immunopositive in $91 \%$ $(20 / 22)$ and $32 \%(7 / 22)$ of cases of hemangioblastoma, respectively. This pattern of widespread staining of CD10 in clear cell renal cell carcinomas supports the diagnostic utility of CD10 in addition to inhibin A when the tissue available for examination may be small.

The Renal Cell Carcinoma Marker has also been reported to be a specific marker for renal cell carcinoma. ${ }^{27} \mathrm{~A}$ high percentage of primary renal cell carcinomas were immunopositive for Renal Cell

Table 3 Positive rates of immunohistochemical studies of EMA, NSE, inhibin A, and CD10 of hemangioblastomas and renal cell carcinomas

\begin{tabular}{|c|c|c|c|c|c|c|c|c|}
\hline & \multicolumn{2}{|c|}{$E M A$} & \multicolumn{2}{|c|}{$N S E$} & \multicolumn{2}{|c|}{ Inhibin $A$} & \multicolumn{2}{|c|}{$C D 10$} \\
\hline & $H B$ & $R C C$ & $H B$ & $R C C$ & $H B$ & $R C C$ & $H B$ & $R C C$ \\
\hline Andrew and Gradwell ${ }^{2}$ & $0 / 5$ & $5 / 5$ & & & & & & \\
\hline Gouldesbrough et al ${ }^{5}$ & $0 / 9$ & $10 / 10$ & $9 / 9$ & $4 / 10$ & & & & \\
\hline Hufnagel et $a l^{23}$ & $0 / 12$ & 9/9 & $3 / 12$ & $0 / 9$ & & & & \\
\hline Hoang and Amirkhan ${ }^{15}$ & $0 / 6$ & & $9 / 9$ & & $25 / 25$ & $0 / 19$ & & \\
\hline Present series & $0 / 7$ & & $7 / 7$ & & $20 / 22$ & $5 / 21$ & $0 / 22$ & $21 / 21$ \\
\hline
\end{tabular}

HB: hemangioblastoma; RCC: renal cell carcinoma. 
Carcinoma Marker. ${ }^{11,28}$ However, since metastatic renal cell carcinoma is associated with a less differentiated tumor, the Renal Cell Carcinoma Marker is positive in relatively lower percentage $(67 \%)$ of metastatic renal cell carcinomas. ${ }^{28} \mathrm{~A}$ negative staining for Renal Cell Carcinoma Marker could not rule out the possibility of metastatic renal cell carcinoma. On the other hand, both low and high nuclear grade renal cell carcinoma expressed the CD10 antigen with characteristic membranous/ Golgi-staining pattern. The unique staining pattern was observed in classic clear cell renal cell carcinoma, in other variants, and in metastatic renal cell carcinoma. $^{9,29}$ CD10 was positive in $100 \%$ metastatic clear cell renal cell carcinoma in a previous report by Ordi et al. ${ }^{29}$ Therefore, we used antibody to CD10 instead of Renal Cell Carcinoma Marker in this study.

In conclusion, in addition to the use of inhibin A, immunoperoxidase staining of paraffin-embedded material using monoclonal anti-CD10 makes a helpful contribution to the differential diagnosis of hemangioblastoma and metastatic clear cell renal cell carcinoma to the central nervous system. Further evaluation of sensitivity and specificity of this panel is indicated before clinical application.

\section{References}

1 Bohling T, Plate KH, Haltia MJ, et al. Von HippelLindau disease and hemangioblastoma. In: Kleihues P, Cavenee WK (eds). Pathology and Genetics of Tumours of the Nervous System. Lyon: IARC, 2000, pp 223-226.

2 Andrew SM, Gradwell E. Immunoperoxidase labeled antibody staining in differential diagnosis of central nervous system haemangioblastomas and central nervous system metastases of renal carcinomas. J Clin Pathol 1986;39:917-919.

3 Mills SE, Ross GW, Perentes E, et al. Cerebellar hemangioblastoma: immunohistochemical distinction from metastatic renal cell carcinoma. Surg Pathol 1990;3:121-132.

4 Seizinger BR, Rouleau GA, Ozelius LJ, et al. Von Hippel-Lindau disease maps to the region of chromosome 3 associated with renal cell carcinoma. Nature 1988;332:268-269.

5 Gouldesbrough DR, Bell JE, Gordon A. Use of immunohistochemical methods in the differential diagnosis between primary cerebellar haemangioblastoma and metastatic renal cell carcinoma. J Clin Pathol 1988;41:861-865.

6 Frank TS, Trojanowski JQ, Roberts SA, et al. A detailed immunohistochemical analysis of cerebellar hemangioblastoma: an undifferentiated mesenchymal tumor. Mod Pathol 1989;2:638-651.

7 Rasmuson T, Grankvist K, Roos G, et al. Neuroendocrine differentiation in renal cell carcinoma: evaluation of chromogranin A and neuron specific enolase. Acta Oncol 1999;38:623-628.

8 Arber DA, Weiss LM. CD 10: a review. Appl Immunohistochem 1997;5:125-140.
9 Chu P, Arber DA. Paraffin-section detection of CD10 in 505 nonhematopoietic neoplasms: frequent expression in renal cell carcinoma and endometrial stromal sarcoma. Am J Clin Pathol 2000;113:374-382.

10 Erdos EG, Schulz WW, Gafford JT, et al. Neutral metalloendopeptidase in human male genital tract: comparison to angiotensin I-converting enzyme. Lab Invest 1985;52:437-447.

11 Avery AK, Beckstead J, Renshaw AA, et al. Use of antibodies to RCC and CD10 in the differential diagnosis of renal neoplasms. Am J Surg Pathol 2000; 24:203-210.

12 Anderson RA, Cambray N, Hartley PS, et al. Expression and localization of inhibin alpha, inhibin/activin betaA and betaB and the activin type II and inhibin beta-glycan receptors in the developing human testis. Reproduction 2002;123:779-788.

13 Fetsch PA, Powers CN, Zakowski MF, et al. Anti- $\alpha-$ inhibin: marker of choice for the consistent distinction between adrenocortical carcinoma and renal cell carcinoma in fine-needle aspiration. Cancer 1999;87: 168-172.

14 Choi YL, Kim HS, Ahn G. Immunoexpression of inhibin alpha subunit, inhibin/activin betaA subunit and CD99 in ovarian tumors. Arch Pathol Lab Med 2000;124:563-569.

15 Hoang MP, Amirkhan RH. Inhibin alpha distinguishes hemangioblastoma from clear cell renal cell carcinoma. Am J Surg Pathol 2003;27:1152-1156.

16 Medeiros LJ, Michie SA, Johnson DE, et al. An immunoperoxidase study of renal cell carcinomas: correlation with nuclear grade, cell type, and histologic pattern. Hum Pathol 1988;19:980-987.

17 Sheahan K, O’Brien MJ, Burke B, et al. Differential reactivities of carcinoembryonic antigen (CEA) and CEA-related monoclonal and polyclonal antibodies in common epithelial malignancies. Am J Clin Pathol 1990;94:157-164.

18 Humphrey PA. Clear cell neoplasms of the urinary tract and the male reproductive system. Semi Diagn Pathol 1997;14:240-252.

19 Reuter VE. Renal tumors exhibiting granular cytoplasm. Semin Diagn Pathol 1999;16:135-145.

20 Sim SJ, Ro JY, Ordonez NG, et al. Metastatic renal cell carcinoma to the bladder: a clinicopathologic and immunohistochemical study. Mod Pathol 1999;12:351-355.

21 Chu P, Wu E, Weiss LM. Cytokeratin 7 and cytokeratin 20 experssion in epithelial neoplasm: a survey of 435 cases. Med Pathol 2000;13:962-972.

22 Becker I, Paulus W, Roggendorf W. Histogenesis of stromal cells in cerebellar hemangioblastomas: an immunohistochemical study. Am J Pathol 1989;134: 271-275.

23 Hufnagel TJ, Kim JH, True LD, et al. Immunohistochemistry of capillary hemangioblastoma: immunoperoxidase-labeled antibody staining resolves the differential diagnosis with metastatic renal cell carcinoma, but does not explain the histogenesis of the capillary hemangioblastoma. Am J Surg Pathol 1989; 13:207-216.

24 Brown DF, Dababo MA, Hladik CL, et al. Hormone receptor immunoreactivity in hemangioblastomas and clear cell renal cell carcinomas. Mod Pathol 1998;11: $55-59$.

25 Bleistein M, Geiger K, Franz K, et al. Transthyretin and transferrin in hemangioblastoma stromal cells. Pathol Res Pract 2000;196:675-681. 
26 Renshaw AA, Granter SR. A comparison of A103 and inhibin reactivity in adrenal cortical tumors: distinction from hepatocellular carcinoma and renal tumors. Mod Pathol 1998;11:1160-1164.

27 Yoshida SO, Imam A. Monoclonal antibody to a proximal nephrogenic renal antigen: immunohistochemical analysis of formalin-fixed, paraffin-embedded human renal cell carcinomas. Cancer Res 1989;49: 1802-1809.

28 McGregor DK, Khurana KK, Cao C, et al. Diagnosing primary and metastatic renal cell carcinoma: the use of the monoclonal antibody 'Renal Cell Carcinoma Marker'. Am J Surg Pathol 2001;25:1485-1492.

29 Ordi J, Romagosa C, Tavassoli FA, et al. CD10 expression in epithelial tissues and tumors of the gynecologic tract: a useful marker in the diagnosis of mesonephric, trophoblastic, and clear cell tumors. Am J Surg Pathol 2003;27:178-186. 